\title{
Terminal Oxidations in Bacillus brevis. Soluble Reduced Nicotinamide Adenine Dinucleotide Oxidase Activity in Bacillus brevis
}

\author{
By G. H. FY NN \\ Department of Biochemistry, The University of Manchester, \\ Institute of Science and Technology, P.O. Box 88, Manchester, M60 I $Q D$ \\ AND B. SEDDON \\ Department of Biochemistry, The University of Liverpool, \\ P.O. Box 147, Liverpool, L69 3BX
}

(Received 17 April 1972)

Bacillus brevis grown so as to produce tyrothricin possesses an active cytochrome-linked NADH oxidase system (Seddon \& Fynn, 197I). Electron-transport particles, containing flavoprotein, a menaquinone and cytochromes of type $a+a_{3}, b, c$ and $o$ possess most of the NADH oxidase activity of this organism during exponential growth (Fynn \& Seddon, 1971 ; Seddon \& Fynn, I971; Fynn, Thomas \& Seddon, 1972). Their NADH oxidase activity is inhibited by classical inhibitors of the respiratory electron-transport chain such as cyanide, antimycin A, 2- $n$-heptyl-4-hydroxyquinoline- $N$-oxide (HQNO), amytal and rotenone showing characteristics typical of a respiratory chain electron-transport system (Seddon \& Fynn, I97I). The oxidative activity of this particulate electron-transport system is also inhibited by levels of tyrothricin and tyrocidine comparable to those produced towards the latter end of the exponential growth phase of this organism and indicates the possibility that such activity may be inhibited in vivo. However, the soluble fraction of this organism is capable of oxidizing NADH by molecular $\mathrm{O}_{2}$ (Seddon \& Fynn, I970; Fynn \& Seddon, I97I). As tyrothricin inhibits the particulate NADH oxidase system its effects on the soluble NADH oxidase are of interest since, if the soluble NADH oxidase is insensitive to tyrothricin, the possibility exists that the soluble NADH oxidase may take over a redox role should the particulate fraction be inhibited.

The present communication describes and discusses properties of the soluble NADH oxidase and the effects on it of inhibitors, including tyrocidine and tyrothricin.

\section{METHODS}

Organism, growth and maintenance. Bacillus brevis ATCC10068 was maintained and grown as described by Seddon \& Fynn (I97I) on an asparagine-glycerol basal salts medium as used by Mach, Reich \& Tatum (I 963). Bacteria were harvested after exponential growth ( 24 to $30 \mathrm{~h}$ ).

Preparation of subcellular fractions. Organisms were harvested from I 1 of media, washed, resuspended in tris- $\mathrm{HCl}$ buffer $(0.1 \mathrm{M}), \mathrm{pH} 7 \cdot 4$, and extruded through a French pressure cell at 0 to $5{ }^{\circ} \mathrm{C}$ and $\mathrm{I} 0000$ to $\mathrm{I} 6000 \mathrm{lb} / \mathrm{in}^{2}$. Centrifugation at $\mathrm{I} 5000 \mathrm{~g}$ removed whole bacteria and larger debris. The crude supernatant fraction was further separated at $105000 \mathrm{~g}$ to yield a particulate fraction (electron-transport particles) and a soluble fraction. This method of fractionation has been described in detail (Seddon \& Fynn, 1971).

Assay of NADH dehydrogenase. Ferricyanide reduction was used to measure dehydrogenase activity. The assay system contained tris- $\mathrm{HCl}$ buffer $(\mathrm{pH} 7 \cdot 4), 300 \mu \mathrm{mol}$; potassium 
ferricyanide, $5 \mu \mathrm{mol}$; KCN (where added), I $2 \mu \mathrm{mol}$; NADH, $0.33 \mu \mathrm{mol}$; and enzyme protein $0 . \mathrm{I}$ to $5.0 \mathrm{mg}$ in a total volume of $3.0 \mathrm{ml}$ at $30^{\circ} \mathrm{C}$.

Assay of NADH-menadione reductase. This was assayed as described by Sanadi, Pharo \& Sordahl (I967) using the following assay system: tris- $\mathrm{HCl}\left(\mathrm{pH}_{7} \cdot 4\right), 300 \mu$ mol; menadione, $0.5 \mu \mathrm{mol} ; \mathrm{KCN}$ (where present), I $2 \mu \mathrm{mol} ; \mathrm{NADH}, 0.33 \mu \mathrm{mol}$ and enzyme protein 0.1 to $5.0 \mathrm{mg}$ in a total volume of $3.0 \mathrm{ml}$ at $30^{\circ} \mathrm{C}$.

Assay of NADH-cytochrome c reductase. Reduction of cytochrome $c$ at $55^{\circ} \mathrm{nm}$ was used as described by Hatefi \& Rieske (1967). The reaction mixture contained tris- $\mathrm{HCl}$ buffer (pH 7.4), $300 \mu \mathrm{mol}$; ferricytochrome $c, 0.05 \mu \mathrm{mol}$; NADH, $0.33 \mu \mathrm{mol} ; \mathrm{KCN}$ (where present), I $2 \mu \mathrm{mol}$ and enzyme protein, 0.2 to $5.0 \mathrm{mg}$ in a total volume of $3.0 \mathrm{ml}$ at $30^{\circ} \mathrm{C}$.

Assay of cytochrome $c$ oxidase. The cytochrome $c$ oxidase activity was measured using a Rank $\mathrm{O}_{2}$ electrode. The rate of $\mathrm{O}_{2}$ uptake was monitored upon addition of ascorbate plus cytochrome $c$ as described by Smith \& Camerino (I963). The reaction mixture contained

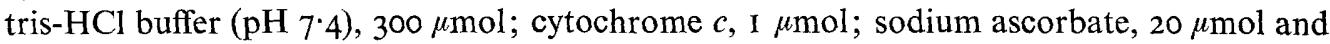
enzyme protein, I to $20 \mathrm{mg}$. Tota lvolume was $3.0 \mathrm{ml}$. A control without enzyme was used to correct for the autoxidation of sodium ascorbate under the conditions of incubation and assays were made at $30^{\circ} \mathrm{C}$.

Difference spectra. Difference spectra were obtained using a Perkin-Elmer model 356 two-wavelength double-beam spectrophotometer operated in the split beam mode. Comparison was made between an anaerobic sample (NADH reduced) and an aerobic sample (treated with $\mathrm{O}_{2}$ ). Carbon monoxide-reduced minus reduced spectra were obtained by bubbling carbon monoxide for up to Io min through the sample cuvette or by mixing the sample contents with an equal volume of carbon monoxide-saturated buffer whilst the reference solution was mixed with an equal volume of $\mathrm{N}_{2}$-saturated buffer.

Protein determination. Protein concentrations were measured by the procedure of Lowry, Rosebrough, Farr \& Randall (I95I) using crystalline bovine plasma albumin (fraction V) as standard.

Chemicals. The chemicals used throughout this work were of A.R. quality when available. More specialized chemicals were obtained from the Sigma Chemical Co., St Louis, Missouri, U.S.A. except those indicated as follows: bovine plasma albumin (fraction V), Armour Pharmaceutical Co. Ltd. Eastbourne Sussex; tyrothricin, tyrocidine and gramicidin from Nutritional Biochemicals Co., Cleveland, Ohio, U.S.A.

\section{RESULTS AND DISCUSSION}

Although the specific activity of the NADH oxidase is usually lower in the soluble fraction than in the electron-transport particles the total activity present can be higher in the soluble fraction. Specific activities measured ranged from 20 to $95 \mathrm{ng}$-atoms $\mathrm{O}_{2} / \mathrm{min} / \mathrm{mg}$ protein with the particulate fraction and from 13 to $29 \mathrm{ng}$-atoms $\mathrm{O}_{2} / \mathrm{min} / \mathrm{mg}$ protein with the soluble fraction and total activities from 2.7 to $8.9 \mu \mathrm{g}$-atoms $\mathrm{O}_{2} / \mathrm{min}$ and from 4.6 to I3. I $\mu$ g-atoms $\mathrm{O}_{2} / \mathrm{min}$ with the particulate and soluble fractions respectively. Low observed NADH oxidase activity in the particulate fraction did not necessarily correspond with high $\mathrm{NADH}$ oxidase activity in the soluble fraction of the same preparation and vice versa. It appears that the particulate $\mathrm{NADH}$ oxidase varies considerably. The soluble NADH oxidase activity was found not to vary much more than twofold. As prolonged (I50 min) centrifugation at $105000 \mathrm{~g}$ did not further decrease the soluble NADH oxidase activity it was inferred that the soluble NADH oxidase activity was substantial in amount and was not a result of contaminating particulate matter. 
Table I. Comparison of the effects of various treatments and substances on the NADH oxidase activities of the $105000 \mathrm{~g}$ particulate and soluble fractions of Bacillus brevis

All measurements were made by following $\mathrm{O}_{2}$ uptake on addition of $\mathrm{NADH}$ at $30^{\circ} \mathrm{C}$ using a Rank $\mathrm{O}_{2}$ electrode (Seddon \& Fynn, I971). All inhibitors except $\mathrm{KCN}$ and atebrin were added as small volumes $(0.05 \mathrm{ml}$ or less) of ethanolic solutions.

\begin{tabular}{|c|c|c|c|}
\hline $\begin{array}{c}\text { Treatment or } \\
\text { addition }\end{array}$ & $\begin{array}{c}\text { Time or } \\
\text { concentration }\end{array}$ & $\begin{array}{c}\text { Percentage inhibition }(-) \text { or } \\
\text { stimulation }(+) \text { of NADH } \\
\text { oxidase activity. } \\
\text { I05000 } g \text { particulate } \\
\text { fraction }\end{array}$ & $\begin{array}{l}\text { I05000 } \boldsymbol{g} \text { soluble } \\
\text { fraction }\end{array}$ \\
\hline Incubation at $100^{\circ} \mathrm{C}$ & $10 \mathrm{~min}$ & -100 & -100 \\
\hline Storage at $-16^{\circ} \mathrm{C}$ & $24 \mathrm{~h}$ & -80 & 0 \\
\hline $\mathrm{KCN}$ & $10 \mathrm{mM}$ & -90 & 0 \\
\hline Antimycin A & $0 . \mathrm{I} \mu \mathrm{mol} / \mathrm{mg}$ protein & -80 & 0 \\
\hline HQNO & $0.5 \mu \mathrm{mol} / \mathrm{mg}$ protein & -55 & 0 \\
\hline Amytal & $2.5 \mu \mathrm{mol} / \mathrm{mg}$ protein & -50 & 0 \\
\hline Rotenone & $0.5 \mu \mathrm{mol} / \mathrm{mg}$ protein & -50 & 0 \\
\hline Atebrin & $4 \mathrm{mM}$ & -30 & -70 \\
\hline Dialysis & $24 \mathrm{~h}$ & - & -40 \\
\hline FMN & $40 \mu_{\mathrm{M}}$ & 0 & +155 \\
\hline FAD & $40 \mu \mathrm{M}$ & 0 & +135 \\
\hline Dialysis + FMN & $24 \mathrm{~h}+40 \mu \mathrm{M}$ & - & +155 \\
\hline Tyrocidine & $2 \mathrm{~mm}$ or $\mathrm{O} . \mathrm{I} \mathrm{mm}$ & -100 & 0 \\
\hline Tyrothricin & $2 \mathrm{mM}$ or $\mathrm{O} . \mathrm{I} \mathrm{mM}$ & $-I 00$ & 0 \\
\hline Gramicidin S & $2 \mathrm{~mm}$ or $\mathrm{o} . \mathrm{I} \mathrm{mm}$ & -100 & 0 \\
\hline Gramicidin & $2 \mathrm{mM}$ or $0.1 \mathrm{~mm}$ & -100 & 0 \\
\hline
\end{tabular}

NADH-reduced minus oxidized difference spectra of the soluble fraction showed that, although the 500 to $600 \mathrm{~nm}$ region of the spectrum was not distinct enough to detect any $\alpha$-peaks of the cytochromes, the Soret region has only one absorbance band with a peak around $420 \mathrm{~nm}$ (possibly a cytochrome of type $c$ ) and suggests the absence of type $a+a_{3}$ cytochrome oxidase. In agreement with this finding $\mathrm{CO}+\mathrm{NADH}-$ reduced minus NADHreduced difference spectra showed nothing in the 400 to $450 \mathrm{~nm}$ region and thus failed to indicate the participation of a carbon monoxide reactive cytochrome. The soluble fraction showed component enzyme activities of $0.8 \mathrm{I} 2, \mathrm{I} \cdot \mathrm{I} 45$ and $0.856 \mu \mathrm{mol}$ substrate oxidized or reduced $/ \mathrm{min} / \mathrm{mg}$ protein at $30{ }^{\circ} \mathrm{C}$ for $\mathrm{NADH}$-cytochrome $c$ reductase, NADH-menadione reductase and NADH dehydrogenase respectively. Cytochrome $c$ oxidase activity could not be detected. The absence of cytochrome $c$ oxidase activity again indicates the lack of cytochromes of type $a+a_{3}$. The overall NADH oxidase activity ( 3 to 29 ng-atoms $\mathrm{O} / \mathrm{min} / \mathrm{mg}$ protein) is much less than any of the three reductase activities assayed and suggests a ratelimiting constraint on the oxidase activity.

NADH-reduced minus oxidized difference spectra also showed a large trough at 450 to $460 \mathrm{~nm}$, indicating the involvement of flavin in the oxidation of NADH by the soluble fraction. The flavin involved with the soluble NADH oxidase is about $70 \%$ of the total flavin content (estimated by dithionite reduction). Dialysis of the soluble fraction at o to $5{ }^{\circ} \mathrm{C}$ against $0 . \mathrm{I}$ M-tris-HCl buffer, $\mathrm{pH} 7 \cdot 4$, led to a loss of $40 \%$ of the soluble NADH oxidase activity. Addition of FMN or FAD restored the activity as shown in Table 1 . The slightly higher activity with FMN may indicate FMN as the flavin component of the NADH oxidase.

Table I shows that the soluble NADH oxidase, in contrast to the particulate NADH oxidase, is not inhibited by cyanide, antimycin A, HQNO, amytal or rotenone. It was, how- 
ever, inhibited by atebrin again implicating flavin. Tyrothricin, tyrocidine, gramicidin S and gramicidin inhibit the particulate NADH oxidase (Table I) but not the soluble NADH oxidase. Whether the electron-transport chain NADH oxidase remains sensitive to tyrothricin production in the intact organism is not yet known, but if it does then the soluble NADH oxidase could provide an uninhibited route for reducing equivalents, though it is unlikely that this would lead to efficient ATP formation since such systems do not normally possess sites of phosphorylation (Asano \& Brodie, 1965).

Soluble NADH oxidase is found in a wide variety of micro-organisms (Dolin, 1961) and the particular function such a system may play is not known. At the end of active growth, sporulating strains of bacilli require an active tricarboxylic acid cycle, presumably for the synthesis of materials necessary for spore formation. During sporulation, although increase in bacterial numbers has stopped, there must be a complete redirection of synthesis geared to the production of the mature spore. A functional tricarboxylic acid cycle could play a central role in the degradation of vegetative material and the synthesis of material essential for the development of the mature spore. Commitment to sporulation appears to be an irreversible process (Gould \& Hurst, I 969) and the possible inhibition of particulate NADH oxidase by tyrothricin production would also be expected to be irreversible since such antibiotics interfere with the integrity of membranes (Hunter \& Schwartz, 1967). The soluble NADH-oxidizing system would ensure the reoxidation of NADH such that the $\mathrm{NAD}^{+} /$ NADH redox couple participation in the tricarboxylic acid cycle could operate even under conditions when the electron-transport NADH oxidase system may be lost or absent.

The authors are indebted to the Science Research Council for the award of a studentship (B.S.) during part of this investigation.

\section{REFERENCES}

Asano, A. \& Brodie, A. F. (1965). The properties of the non-phosphorylative electron transport by-pass enzymes of Mycobacterium phlei. Biochemical and Biophysical Research Communications 19, I21-126.

Dolin, M. I. (196I). In The Bacteria, vol. 2, chap. 9. Edited by I. C. Gunsalus and R. Y. Stanier. New York: Academic Press.

Fynn, G. H. \& SEDdon, B. (1971). Terminal oxidations in Bacillus brevis ATCC 10068. III. Evidence of TCA cycle enzyme activity. Archiv für Mikrobiologie 79, 274-279.

FynN, G. H., Thomas, D. V. \& Seddon, B. (1972). On the role of menaquinone in the reduced nicotinamide adenine dinucleotide oxidative pathway of Bacillus brevis. Journal of General Microbiology 70, 27I-275.

Gould, G. W. \& Hurst, A. (1969). The Bacterial Spore. New York: Academic Press.

HATEFI, Y. \& RIESKE, J.S. (1967). In Methods in Enzymology, vol. 10, section III, 41, p. 225. Edited by R. W. Estabrook and M. A. Pullman. New York: Academic Press.

Hunter, F. E. \& Schwartz, L. S. (I967). In Antibiotics, vol. I, pp. 636, 643. Edited by D. Gottlieb and P. D. Shaw. New York: Springer-Verlag.

Lowry, O. H., Rosebrough, N. J., Farr, A. L. \& Randall, R. J. (195I). Protein measurement with the Folin phenol reagent. Journal of Biological Chemistry 193, 265-275.

MaCH, B., REICH, E. \& TAтUM, E. L. (I963). Separation of the biosynthesis of the antibiotic polypeptide tyrodicine from protein biosynthesis. Proceedings of the National Academy of Sciences of the United States of America, 50, I75-18I.

Sanadi, D. R., Pharo, R. L. \& Sordahl, L. A. (1967). In Methods in Enzymology, vol. 10, section Iv, 54, p. 297. Edited by R. W. Estabrook and M. A. Pullman. New York: Academic Press.

SEDDON, B. \& FYNN, G. H. (1970). Terminal oxidations in Bacillus brevis. ATCC 10068. I. The measurement of the NADH oxidase activity of Bacillus brevis ATCC 10068. Biochimica et biophysica acta 216, 435-438.

SEDDON, B. \& FYNN, G. H. ( I 971). Terminal oxidations in Bacillus brevis. II. The electron-transport system of Bacillus brevis. Archiv für Mikrobiologie 77, 252-26I.

SMith, L. \& CAMERINo, P. W. (I963). Comparison of polarographic and spectrophotometric assays for cytochrome $c$ oxidase activity. Biochemistry 2, 1428-1432. 